\section{Diagnosing resistance}

\section{By Lauren Martz, Staff Writer}

It might be a day late and a dollar short, but the U.S. government is finally getting around to addressing what many experts think is the big unserved need in antibiotic resistance-new diagnostics. Faster, more sensitive and versatile diagnostic technologies that can keep up with the emergence of resistant strains are needed both for improving treatment and optimizing clinical trials.

"Diagnostics are the key. It is just that we are far away from that right now and need to stimulate that," said Janet Woodcock, director of the FDA's Center for Drug Evaluation and Research at a hearing last month about antibiotic resistance held by the U.S. House of Representatives' Energy and Commerce Committee's Subcommittee on Health.

The hearing was part of the committee's 21st Century Cures initiative and revolved around strategies for combating antibiotic resistance and fostering new drug development. Although the main focus was on ways to modify clinical practice and create incentives for new therapeutics, several participants highlighted the urgent need for new diagnostics.

A day earlier, the White House announced a $\$ 20$ million prize for the development of a rapid point-of-care diagnostic for resistant infections, a national strategy for solving problems of antibiotic resistance and the publication of a report from the President's Council of Advisors on Science and Technology that included the importance of diagnostics in reducing the inappropriate use of antibiotics.

Experts at the hearing agreed that existing diagnostic capabilities do not adequately address the problem of antibiotic resistance.

"Louis Pasteur and Alexander Fleming would recognize the methods we use today because they invented them, so there is a lot of room at the top for improvement," Woodcock said at the hearing. "If we could bring diagnosis of infectious diseases into the 21 st century, we would have made a huge advance and really accelerated the development of therapy."

The consensus of the participants was that more sensitive and faster diagnostics are needed both to help physicians pick the right antibiotic and to help companies select the right patient population for clinical trials.

"Diagnosis should be the foundation of therapy, and unfortunately in the infectious disease space often you are treating a person well before you know what the person has, and this is a fundamental problem," said Woodcock.

Using the wrong antibiotic not only fails to treat the patient properly but also contributes further to the growth of resistant strains. Woodcock noted-on the plus side-that the rapid strep test has reduced the misuse of antibiotics in patients with colds or other upper respiratory tract infections that resemble strep throat.

John Rex, SVP and head of infection global medicine development at AstraZeneca plc, told SciBX that in drug development, the lack of fast and specific diagnostics increases trial size and thus development costs.

"About one in four, or maybe one in three, patients that I enroll in a clinical trial are actually infected with the organism of interest. The rest of the patients don't give useful microbiotic data. All isn't lost because they do provide tolerability data, but they don't help us know if the drug is working," said Rex. "If a rapid diagnostic could simply make our guesses better, that would be fantastic. Everyone I enroll costs time, money and work."

\section{No GAIN for diagnostics}

The government launched a stimulus for new antibiotic therapies with the Generating Antibiotic Incentives Now (GAIN) Act in 2012 that provides extended exclusivity for new antibiotics and earmarks them for priority review by the FDA. That was followed last December by the introduction of the Antibiotic Development to Advance Patient Treatment (ADAPT) Act, a bill to improve the economics of antibiotic development for companies.

For therapeutics, the measures are starting to pay off. Three new antibiotics have been approved this year after being designated as Qualified Infectious Disease Products (QIDPs) under GAIN, and at least 36 more molecules in development have QIDP designation.

The approved QIDP-designated products include Dalvance dalbavancin from Durata Therapeutics Inc. and Gruppo Angelini; Sivextro tedizolid phosphate (TR-701) from Cubist Pharmaceuticals Inc., Dong-A Pharmaceutical Co. Ltd. and Bayer AG; and Orbactiv oritavancin from The Medicines Co. All three drugs are approved to treat acute bacterial skin and skin structure infections (ABSSSIs) caused by Gram-positive bacteria including methicillin-resistant Staphylococcus aureus (MRSA).

The last two years have seen a clear uptick in venture financing for companies developing new antibacterial therapies, whereas the venture money going to new diagnostics has remained low and has barely changed in five years. Similarly, over the past 5 years, there have consistently been 5 - to 10 -fold more companies formed to develop therapeutics for bacterial infections than to develop diagnostics for them (see Figure 1, "Venture financing for therapies and diagnostics for bacterial infections").

Ankit Mahadevia, entrepreneur in residence in the life sciences group at Atlas Venture, told SciBX that the new initiatives have had an impact on VC investment in new antibiotic therapeutics.

"From a VC perspective, anti-infective therapies are very attractive for investment," he said. "With the regulatory changes, the cost of development is decreasing due to decreased trial size, and GAIN makes revenues higher. We also have a clear realization from payers that we need to pay more for the effective therapeutics."

But for diagnostics, the outlook is less rosy. "On the diagnostic side in general, the last few years have been challenging. There are few investors, and reimbursement is cloudy. The market needs for new 
I

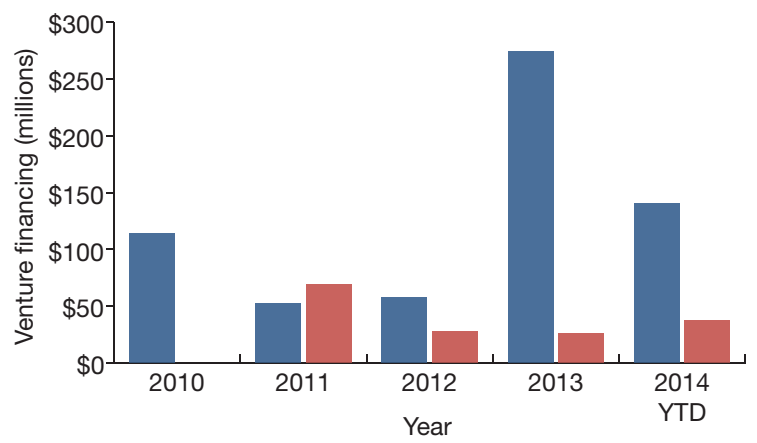

II

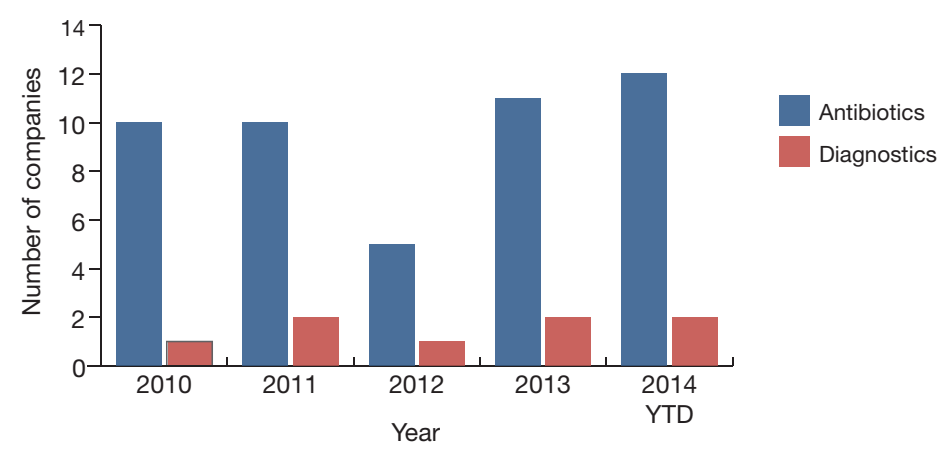

Figure 1. Venture financing for therapies and diagnostics for bacterial infections. (I) Total amount of venture financing for newly formed companies developing therapies or diagnostics for bacterial infections.

(II) Number of newly formed companies developing therapeutics or diagnostics for bacterial infections that received venture financing.

Source: BCIQ: BioCentury Online Intelligence

diagnostics are clearly there, but there is not a magic bullet to fix the health of entrepreneurial companies in diagnostics," Mahadevia told SciBX.

The problem is largely that without incentives such as those in the GAIN and ADAPT acts, the economics of developing diagnostics for antibiotic resistance are not attractive for companies or investors.

Oliver Schacht, CEO of diagnostics company Curetis AG, added, "As bad as pricing is for antibiotic drugs, it is even worse for diagnostics. To solve this problem, we need to put diagnostics in a spot where the health economic benefits are realized and the pricing and reimbursements are set accordingly."

Schacht noted that pricing for diagnostics is based on a cost-plus model, which is too low to allow companies to recover development costs. Value-based pricing could solve the problem, he said.

Stakeholders who spoke with SciBX agreed that the White House's $\$ 20$ million prize is a step in the right direction but said it is not even remotely enough.

Joen Johansen, head of marketing at Accelerate Diagnostics Inc., told SciBX, "It is certainly a good idea to provide financial incentives, and this prize is a good first step to help get projects off the ground, but it will take quite a bit more to get diagnostics to the market. Diagnostics don't require the same level of investment as therapeutics, but many millions more than that would be needed."

Several participants at the hearing proposed that one solution lies in increased funding for basic research at the NIH or universities to stimulate discoveries that can be commercialized.

"If we do not have enough basic science, the pipeline that flows to venture capital and then to the larger companies runs dry," Kevin Outterson said at the hearing. Outterson is a professor of law and of health law, bioethics and human rights at Boston University.

But others disagreed that increased public funding would drive commercial innovation in the absence of incentives on the commercial side.

"If you don't have somebody with the profit motive-a company, a pharmaceutical company, big or small-you can sit there doing some basic research for 100 years," but it will not get the industry where it needs to be, said Rep. Phil Gingrey, D-Ga. Gingrey was one of two congressmen who introduced the ADAPT Act in the House of Representatives.

Adrian Thomas advocated a combination of approaches to cover both academic research and commercial incentives that would promote point-of-care diagnostics, biomarkers and new diagnostic capabilities and would help advance clinical research. He said that large grants, funding and prizes would make the most sense, in addition to tax credits, to encourage broad-based academic research as well as broadbased technology development-which has shorter timelines and is managed differently than therapeutic development. Thomas is VP of global market access, commercial strategy operations and global public health at Johnson \& Johnson's Janssen Inc. unit.

Dennis Dixon, chief of the bacteriology and mycology branch at the NIH's National Institute of Allergy and Infectious Diseases, told SciBX that the institute has multiple funding opportunities related to diagnostics development for antibiotic resistance, which include awards for investigator-initiated research, small business grants, special programs for diagnostic development, and clinical and preclinical services for diagnostic development.

\section{Need for speed}

Because patients usually receive treatment before their infection is properly characterized, one of the key needs in new diagnostics is faster readouts.

"The gold standard for diagnosing bacterial infections is growing the bacteria in culture for one to two days or more-depending on the type of bacteria - to identify the causal pathogen. Then, an additional 12-24 hours are required to conduct an antibiotic sensitivity screen," said Schacht. "Without a diagnosis for several days, physicians don't know which type of pathogen is responsible for the infection and treat patients with broad-spectrum antibiotics. This is the wrong treatment or inadequate in $30 \%-40 \%$ of cases."

According to Dixon, there have been some major breakthroughs in rapid diagnostics for certain bacterial species using molecular diagnostics. These tests scan amplified genetic material or proteins for specific sequences present in the pathogen of interest.

However, AstraZeneca's Rex cautioned that although rapid readouts are valuable, molecular tests only detect resistance mutations that have 
Table 1. Selected diagnostic tests in development for bacterial infections. Diagnostics are listed from most to least advanced stage of development.

Source: BCIQ: BioCentury Online Intelligence; company websites

\begin{tabular}{|c|c|c|c|c|}
\hline Company & Product(s) & Indication(s) & Description & Development phase \\
\hline $\begin{array}{l}\text { Akers } \\
\text { Biosciences Inc. } \\
\text { (NASDAQ:AKER; } \\
\text { LSE:AKR) }\end{array}$ & $\begin{array}{l}\text { PIFA PLUSS Chlamydia } \\
\text { Assay }\end{array}$ & Chlamydia infection & $\begin{array}{l}\text { Point-of-care assay to detect chlamydia from finger-stick } \\
\text { blood sample }\end{array}$ & Pivotal \\
\hline $\begin{array}{l}\text { Diaxonhit } \\
\text { (Euronext:ALEHT) }\end{array}$ & BJI InoPlex & $\begin{array}{l}\text { Articular prosthesis } \\
\text { infections }\end{array}$ & $\begin{array}{l}\text { Noninvasive, multiparameter serologic test that detects } \\
\text { bacterial antigens }\end{array}$ & Pivotal \\
\hline $\begin{array}{l}\text { Accelerate } \\
\text { Diagnostics Inc. } \\
\text { (NASDAQ:AXDX) }\end{array}$ & $\begin{array}{l}\text { Tests using the } \\
\text { Accelerate ID/AST } \\
\text { system }\end{array}$ & Bacterial infections & $\begin{array}{l}\text { Culture-free genotypic and phenotypic microbe analysis } \\
\text { to diagnose bacterial infections and assess antibiotic } \\
\text { susceptibility }\end{array}$ & Pilot \\
\hline Atlas Genetics Ltd. & $\begin{array}{l}\text { Tests using the Atlas io } \\
\text { system }\end{array}$ & $\begin{array}{l}\text { Chlamydia; gonorrhea; } \\
\text { methicillin-resistant } \\
\text { Staphylococcus aureus } \\
\text { (MRSA) }\end{array}$ & Point-of-care diagnostic that detects bacterial nucleic acids & Pilot \\
\hline $\begin{array}{l}\text { bioMerieux S.A. } \\
\text { (Euronext:BIM) }\end{array}$ & $\begin{array}{l}\text { FilmArray Meningitis/ } \\
\text { Encephalitis Panel }\end{array}$ & $\begin{array}{l}\text { Community-acquired } \\
\text { meningitis }\end{array}$ & $\begin{array}{l}\text { In vitro multiplex PCR platform that detects } 16 \text { bacterial, } \\
\text { viral and fungal pathogens known to cause community- } \\
\text { acquired meningitis and encephalitis }\end{array}$ & Pilot \\
\hline $\begin{array}{l}\text { Global } \\
\text { BioDiagnostics Corp. }\end{array}$ & TB REaD & Tuberculosis & Point-of-care diagnostic to detect tuberculosis & Pilot \\
\hline $\begin{array}{l}\text { Great Basin Corp. } \\
\text { (NASDAQ:GBSN) }\end{array}$ & Staph ID/R test & Staphylococcus & $\begin{array}{l}\text { Automated molecular diagnostic combining helicase- } \\
\text { dependent amplification of target sequence in the RNA } \\
\text { polymerase gene with a chip-based array }\end{array}$ & Pilot \\
\hline $\begin{array}{l}\text { Meridian } \\
\text { Bioscience Inc. } \\
\text { (NASDAQ:VIVO) }\end{array}$ & $\begin{array}{l}\text { Illumigene Chlamydia } \\
\text { trachomatis; illumigene } \\
\text { Neisseria gonorrhoeae }\end{array}$ & Chlamydia; gonorrhea & $\begin{array}{l}\text { Molecular platform based on DNA amplification utilizing } \\
\text { loop amplification technology }\end{array}$ & Pilot \\
\hline $\begin{array}{l}\text { Akonni } \\
\text { Biosystems Inc. }\end{array}$ & $\begin{array}{l}\text { TruArray test for MDR- } \\
\text { TB; TruArray test for } \\
\text { MRSA }\end{array}$ & $\begin{array}{l}\text { Multidrug-resistant } \\
\text { tuberculosis; MRSA }\end{array}$ & $\begin{array}{l}\text { Point-of-care mid-multiplex assay using Akonni's } \\
\text { TruDiagnosis platform }\end{array}$ & Preclinical \\
\hline
\end{tabular}

been seen in the past. "This is a problem because bacteria are constantly evolving new methods of resistance," he said.

Johansen added that although molecular diagnostics can identify a known pathogen or mutation, the technique does not provide a clear indication that the organism will respond to a certain drug because other resistance mechanisms may also be at play.

Indeed, for these reasons Dixon said that molecular diagnostics are not at the point of replacing bacterial cultures.

However, there are intrinsic limitations to how much the timelines of culture-based techniques can be shortened.

"The problem with accelerating culture-based tests is that you hit a biologic speed limit. Organisms will only grow so fast. We need to allow a certain number of growth cycles that each take about 60-90 minutes to get the bacteria really growing," said Rex. "What people have experimented with is trying to find ways to get the culture down to a few hours with fewer cycles, but we can't get much shorter than that."

One solution might be in bacterial cell imaging methods that monitor the response of bacteria to therapeutics on an individual-cell basis-a strategy that could enable a rapid susceptibility readout and avoid the long culture process.

Accelerate Diagnostics is developing the Accelerate ID/AST diagnostic platform using this approach and hopes to seek marketing authorization for a test in 2016.

\section{Cleaning up}

At least 11 companies have new diagnostic tests in development for bacterial infections (see Table 1, "Selected diagnostic tests in development for bacterial infections").

Although the different technologies in development all have advantages, there are several common problems they still need to address, such as sample contamination, assay sensitivity, identifying the responsible pathogen and measuring efficacy in biofilms.

"Direct from specimen is the key enabling technology for really, really rapid diagnostics," said Rex.

The problem, according to Schacht, is that "native clinical samples
"Louis Pasteur and Alexander Fleming would recognize the methods we use today because they invented them, so there is a lot of room at the top for improvement." - Janet Woodcock, Food and Drug Administration are messy and heterogeneous, especially in tissues affected by infectious diseases such as sputum. The samples are ugly, they may have blood in them and they are all different. For a rapid bedside test, we need to develop one test that can handle very diverse clinical samples."

Certain types of tests such as nextgeneration sequencing also require cleaner samples than others and may be less well suited for rapid diagnostics, added Schacht.

Another challenge is developing tests with sufficient sensitivity. "Few bacteria can cause a significant response from the immune system, so we need a very sensitive test for many kinds of infections," said Johansen.

Detecting the bacteria is only part of the problem. The other part is determining whether the bacteria tested are the responsible pathogens. 
For example, Dixon told SciBX that rapid molecular diagnostic tests for strep, chlamydia and tuberculosis have been breakthrough successes. "These tests are effective because they are each detecting bacteria that are not normally present and do so where the bacteria are present in large numbers," he said. "This is versus infections in a hospital setting that are caused by bacteria that are also part of the normal flora. These infections set a much higher bar on the threshold for what will be

"Direct from specimen is the key enabling technology for really, really rapid diagnostics." -John Rex, AstraZeneca plc clinically useful tests."

Prabhavathi Fernandes, founder, president and CEO of Cempra Inc., told SciBX that this problem is very significant in diagnosing the cause of pneumonia. "Pneumonia is caused by a number of pathogens that are all found in the saliva of healthy people. The question is, how do you distinguish the true infection from colonizing bacteria? The answer is in the numbers, which may show which is taking over."

Finally, identifying antibiotic susceptibility of chronic bacterial infections poses a separate set of challenges. Most significantly, antibiotics effective against free-floating bacteria may not be effective against biofilms.

"Minimum inhibitory concentration tests for antibiotic susceptibility test free-floating, planktonic-phase bacteria. In real life and especially in chronic infections, bacteria grow as a biofilm community and are one to two thousand times more resistant than the free-floating counterparts," said Amin Omar, technical services supervisor at Innovotech Inc.

However, some researchers think that diagnostic developers could learn from the success achieved in diagnosing MRSA.

"A few years ago, MRSA was the hot challenge, and companies did a fantastic job of developing a rapid test for the resistance," Schacht said. The GeneXpert system marketed by Cepheid Inc. can diagnose MRSA in 66 minutes or less.
Bacterial gene editing with clustered, regularly interspaced short palindromic repeats (CRISPR) may be poised for a similar breakthrough. Two new studies show that it may be possible to use CRISPR to create tailored therapies that eliminate specific resistance genes or resensitize bacteria to existing antibiotics. ${ }^{1,2}$

"Resistance is cyclic. Any new drugs, if used long enough even appropriately, ultimately will see some level of resistance. There isn't a simple, permanent fix, and we need continuous innovation to keep up with bacterial evolution," said Rex.

Martz, L. SciBX 7(41); doi:10.1038/scibx.2014.1196

Published online Oct. 23, 2014

\section{REFERENCES}

1. Citorik, R.J. et al. Nat. Biotechnol.; published online Sept. 21, 2014; doi:10.1038/nbt.3011

2. Bikard, D. et al. Nat. Biotechnol.; published online Oct. 5, 2014; doi:10.1038/nbt.3043

\section{COMPANIES AND INSTITUTIONS MENTIONED}

Accelerate Diagnostics Inc. (NASDAQ:AXDX), Tucson, Ariz. AstraZeneca plc (LSE:AZN; NYSE:AZN), London, U.K. Atlas Venture, Cambridge, Mass.

Bayer AG (Xetra:BAYN), Leverkusen, Germany

Boston University, Boston, Mass.

Cempra Inc. (NASDAQ:CEMP), Chapel Hill, N.C.

Cepheid Inc. (NASDAQ:CPHD), Sunnyvale, Calif. Cubist Pharmaceuticals Inc. (NASDAQ:CBST), Lexington, Mass. Curetis AG, Holzgerlingen, Germany Dong-A Pharmaceutical Co. Ltd. (KSE:000640), Seoul, South Korea

Durata Therapeutics Inc. (NASDAQ:DRTX), Chicago, III. Food and Drug Administration, Silver Spring, Md. Gruppo Angelini, Rome, Italy Innovotech Inc. (TSX-V:IOT), Edmonton, Alberta, Canada Johnson \& Johnson (NYSE:JNJ), New Brunswick, N.J. National Institute of Allergy and Infectious Diseases, Bethesda, Md.

National Institutes of Health, Bethesda, Md. The Medicines Co. (NASDAQ:MDCO), Parsippany, N.J. 